
\title{
$\angle S$ Research Square \\ Acidic Condition Accelerates Base Cation Release from Purple Rock in Southwestern China
}

\section{Jixia Zhao}

Yunnan Agricultural University

Chunpei Li

Yunnan Agricultural University

\section{Chuanhao Lu}

Chinese Academy of Sciences, Chinese Academy of Science \& Water Resources Ministry

Limei Deng

Chinese Academy of Sciences, Chinese Academy of Science \& Water Resources Ministry

Gangcai Liu ( $\nabla$ liugc@imde.ac.cn )

Chinese Academy of Sciences, Chinese Academy of Science \& Water Resources Ministry

Maopan Fan

Yunnan Agricultural University

\section{Research Article}

Keywords: Cation release rates, purple rock, Entisols, acidic condition

Posted Date: February 21st, 2022

DOI: https://doi.org/10.21203/rs.3.rs-1333853/v1

License: (1) This work is licensed under a Creative Commons Attribution 4.0 International License. Read Full License 


\section{Abstract}

In spite of the fact that rock weathering performs an essential task in the evolution of the Earth's surface, the quantitative assessment between $\mathrm{pH}$ and rates of chemical weathering remain unclear. This study aims to characterize the chemical weathering rate of purple rocks (Entisols in USDA Taxonomy) and then develops a model to calculate the release rates of base cations $\left(\mathrm{K}^{+}, \mathrm{Na}^{+}, \mathrm{Ca}^{2+}\right.$ and $\left.\mathrm{Mg}^{2+}\right)$ under various $\mathrm{pH}$ conditions. Two types of purple rock were sampled from the Shaximiao Group $\left(J_{2} s\right)$ and Penglaizhen Group $\left(J_{3} p\right)$, and a series of laboratory experiments were performed by soaking the purple rocks in solutions with pHs from 2.5 to 7.0 , over 24 treatment cycles. The results showed that the release rates of base cations apparently increased as the $\mathrm{pH}$ decreased. The release of $\mathrm{Ca}^{2+}$ was the dominant process of chemical weathering in $\mathrm{J}_{3} \mathrm{p}$ under various $\mathrm{pH}$ treatments, while $\mathrm{K}^{+}$and $\mathrm{Na}^{+}$were remarkably high in $\mathrm{J}_{2} \mathrm{~s}$ (with the exception of the $\mathrm{pH} 2.5$ treatment). Quantitative analysis revealed that the rate of cation release was significantly related to the $\mathrm{H}^{+}$concentration $(p<0.001)$ and the air temperature $(p<0.001)$. The relationship between cation release and acidity was found to be an exponential function. Our results suggested that solution acidity serves as an important driving force for cation release rates from purple rocks and that environmental acidification would enhance rock weathering.

\section{Introduction}

Rock weathering can significantly change the physical characteristics of unconsolidated deposit (Birkeland,1999), and lead to transformation/devastation of the topographies, whilst it can drastically affect the topographic evolution of the tectonic formation of piedmont of mountains (Eppes et al., 2002). As rock weathering represents the initial stage during the development of landforms and the transformation from bedrock to soil, it not only provides a habitat for terrestrial biota but also supplies the cations that determine the long-term availability of plant nutrients (Duan et al., 2002). Additionally, the mineral weathering of bedrock is usually considered to be a crucial stage in the geochemical cycle because it directly affects all terrestrial life (Goldsmith et al., 2010). For example, if the balance between base cation release via chemical weathering and loss through plant uptake is upset, then acidification occurs (Langan et al., 1996; Sverdrup and Warfvinge, 1998). Therefore, the rate of base cations that are released from parent materials through chemical weathering is a critical concern when investigating soil fertility, plant nutrient supply, buffering capacities of soils and surface water quality (Hornung et al., 1990; Langan et al., 1995).

The rate of chemical weathering of rocks is affected by a variety of influencing factors, such as the rock's material properties, topography, climatic conditions (e.g., temperature, precipitation and the chemical composition and pH of rainfall) and biological activity (Nesbitt et al., 1980; Chen et al., 1997; Kirschbaum et al., 2005; Green et al., 2006; Huang et al., 2013). Currently, critical studies have been undertaken on the various factors that impact rock weathering, and it has been recognized that climate factors are most responsible for the weathering rate, in particular temperature and moisture (Warke, 2000). Although a number of investigations have revealed the $\mathrm{pH}$ dependence of the slake-durability of rocks (Gupta and Ahmed, 2007; Zhou et al., 2005), the influences of acids on the rate of disintegration as well as chemical weathering of rocks have not been fully investigated. Recently, the combination of acid precipitation (known as 'acid rain') and secondary pollutants (formed through $\mathrm{SO}_{2}, \mathrm{NO}_{x}$ and $\mathrm{NH}_{3}$ emissions) has become of an increasing global environmental concern. China has become the third largest global source of acid deposition, following North America and Europe 
(Rodhe et al., 2002). Further, acidic rain in both small mountain villages and great cities has been observed, especially in the regions to the south of the Yangtze River, in the basin of Sichuan, and to the east of the Qinghai-Tibet Plateau (Ling et al., 2007). Acidic solutions should exert a strong influence on weathering rates through inputs of $\mathrm{H}^{+}$ions, which displace the base cations from their binding sites, limiting their capacity to neutralize acid input and increasing the cation concentration in water (Liu et al., 1990). Related studies have shown that acidic precipitation not only directly accelerates chemical weathering rates through the input of $\mathrm{H}^{+}$ ions (Huang et al., 2013), but also indirectly drives base cation release through the proton production from nitrogen transformation (Huang et al., 2015). The rate of chemical weathering is therefore crucial to determining whether soils are sensitive to the effects of acid. However, the rate at which base cations are released through rock weathering in acidic environments has always been difficult to measure and quantify because of a variety of environmental factors.

Herein, the considered purple rock is a sedimentary rock, mostly distributed in the southern zone of the Yangtze River and, most commonly, in the Sichuan Basin of Southwest China. These outcrops account for $51.5 \%$ of the total area of purple rock distribution in China (He, 2003). Due to its primary characteristic of fast physical weathering, purple rock is easily broken into gravel or fragments of rock by both nature and economic factors, and crops can be planted directly on weathered products. The nutrients within the soils that derive from purple rocks are largely released through the weathering process and especially comprise $\mathrm{P}$ - and $\mathrm{K}$-rich minerals; purple rock is generally considered the nutritional base for purple soils (Zhu et al., 1999; He, 2003). Much of the work regarding the study of the physical weathering of purple rock has largely been based on the impacts of moisture and temperature (Zhang et al., 2012; Zhang et al., 2013; Zhang et al., 2015; Zhang et al., 2017). However, the effect of variations in $\mathrm{pH}$ on chemical weathering is not yet clear, and other environmental factors may also play a role, making it difficult to predict weathering characteristics under acidic conditions. Therefore, in this study, we aim to determine the quantitative effects of varying acidic solutions on rock decay (weathering) when it is applied to purple rock by using controlled laboratory experiments.

\section{Materials And Methods}

\subsection{Materials}

The samples of fresh purple rocks utilized in the experimental measurements were chosen from purple and redbrown mudstones of the group of the Shaximiao $\operatorname{Group}\left(\mathrm{J}_{2} \mathrm{~S}\right)\left(\mathrm{E} 104^{\circ} 51^{\prime}, \mathrm{N} 29^{\circ} 44^{\prime}\right)$, and the purple and brown sandy mudstone of the Penglaizhen Group $\left(\mathrm{J}_{3} \mathrm{p}\right)\left(\mathrm{E} 105^{\circ} 23^{\prime}, \mathrm{N}^{\circ} 0^{\circ} 6^{\prime}\right)$ in Sichuan Basin, all laid down in the Jurassic period. Sichuan Basin possesses a subtropical, monsoon climate with a yearly mean temperature between 14 and $19{ }^{\circ} \mathrm{C}$ and average yearly precipitation of around $850 \mathrm{~mm}$. Most of the precipitation occurs between May and October. To better reflect the authenticity of weathering characteristics in an acidic environment, the fresh purple rock samples without acid effects were selected. Then, all of the samples were taken and treated at the Field Observation and Science Research National Station of Farmland Ecosystem in

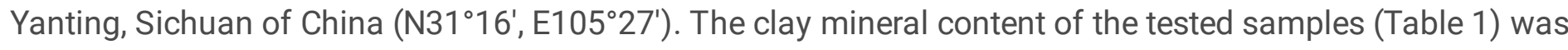
determined using the X-ray diffraction method (Zhang and Fan, 2003). The elements $\mathrm{K}, \mathrm{Na}, \mathrm{Ca}$ and $\mathrm{Mg}$ (Table 2) were determined by atomic absorption spectrophotometry. Si, Al, Fe and Ti were using the gravimetricmolybdenum blue photometric method, the fluoride replacement method, the dichromate volumetric method, and the hydrogen peroxide photometric method, respectively (Ministry of Geology and Resources, 2002). 
About 58\% of precipitation in southwestern China has a pH value between 4.5 and 5.6 (Zhou et al., 2017). The outcomes of acidic rain surveyed by the Sichuan Meteorological Bureau of Dazhou, Xichang, Chengdu, Panzhihua, E'meishan, and Anyue from 2006 to 2013 demonstrated that in Sichuan province, the average frequencies of stronger acids $(\mathrm{pH} \leq 4.0)$ are about $17 \%$ and the average $\mathrm{pH}$ of precipitation is about 4.74 (Zhao et al., 2015). Moreover, it has been detected that the $\mathrm{pH}$ value of precipitation in some regions of the Sichuan Basin was very low and ranged from 3.0-3.5 (Wang and Han, 2011; Zhao et al., 2013), and the nitric acid and sulfuric acid were the fundamental resources of acidity within the precipitation. The molar ratio of $\mathrm{SO}_{4}{ }^{2-}$ to $\mathrm{NO}_{3}{ }^{-}$is around 4:1 (Zhang et al., 2010; Yang et al., 2014). On the basis of this range, a mixture of synthetic acid solutions comprising $\mathrm{H}_{2} \mathrm{SO}_{4}$ and $\mathrm{HNO}_{3}$ with a ratio of the molar concentrations of around 4:1 was prepared. However, a pH lower than 3.0 is unusual in natural environments, the outcomes of acidity on chemical weathering are relatively long procedures, and in the simulation assessment, a lower $\mathrm{pH}$ is frequently utilized to simulate the long-lasting impacts of an acidic media within the natural environments for diminishing the involvement of humidity, temperature, and other external parameters (Liu et al., 2010). Hence, the preparation of acidic solutions with values of $\mathrm{pH}$ of $5.6,4.5,3.5$, and 2.5 was carried out through dilution of the stock solution by utilizing deionized water. In these experiments, the deionized water (with a pH of 7.0) was utilized as a control (CK).

\subsection{Experimental procedure}

To ensure homogeneity, the samples for each treatment were selected from the same block of purple rock. Cut the parent rock sample into small pieces, and each cube was then shaped into a rough sphere with a mass of $660 \pm 3 \mathrm{~g}$. All of the tests were conducted in triplicate with the following detailed procedure.

All the prepared experimental samples were randomly placed into $500 \mathrm{ml}$ glass beaker. Then, add $300 \mathrm{ml}$ of acid solution to each beaker, and it was ensured that all the samples were submerged. After soaking for 72 hours, each solution was filtered and collected to determine the base ion $\left(\mathrm{K}^{+}, \mathrm{Na}^{+}, \mathrm{Ca}^{2+}, \mathrm{Mg}^{2+}\right)$ concentration in solution. Put the residual rock cuttings on the filter paper back into the beaker and dried for more than 24 hours at $105^{\circ} \mathrm{C}$ to a constant weight. All of these decayed products were prepared for the next acid solution treatment after cooling, this procedure represented one treatment cycle. Particles of weathered products less than $2 \mathrm{~mm}$ in diameter are commonly regarded as soil particles (Zhu et al., 1999; He, 2003). Therefore, a total of 24 cycles were carried out for all of the treatments because the disintegration rate of the purple rock treated with each acid solution were exceed $90 \%$, which indicated that the disintegration process has basically stopped. Herein, the $\mathrm{pH}$ of the collected filtered solutions was determined by a pHS-3E acidimeter, and ion chromatography was used to determine $\mathrm{Na}^{+}, \mathrm{K}^{+}, \mathrm{Ca}^{2+}$ and $\mathrm{Mg}^{2+}$ in the filtered solution.

\subsection{Calculation of cation release in the treatment cycle}

Based on the solution volume and the ions collected in each soaking test, the amount of $\mathrm{K}^{+}, \mathrm{Na}^{+}, \mathrm{Ca}^{2+}$ and $\mathrm{Mg}^{2+}$ in the filtered solution were calculated in accordance with the following equation [1]:

$S_{i}=C_{i} \cdot V_{i} /\left(M_{i} \cdot m \cdot 1000\right)[1]$ 
where $S_{i}$ represents the released amounts of $\mathrm{K}^{+}, \mathrm{Na}^{+}, \mathrm{Ca}^{2+}$ and $\mathrm{Mg}^{2+}$ during each treatment cycle $\left(\mathrm{mmol} \mathrm{kg}^{-1}\right)$; $i$ is $\mathrm{K}^{+}, \mathrm{Na}^{+}, \mathrm{Ca}^{2+}$ and $\mathrm{Mg}^{2+} ; C_{i}$ is the concentration of each cation in the filtered solution (ppm); $V_{i}$ represents the volume of filtered solution collected after each soaking $(\mathrm{ml}) ; M_{i}$ is the relative atomic mass of each atom $(\mathrm{K}-39, \mathrm{Na}-23, \mathrm{C},-40$ and $\mathrm{Mg}-24)$ and $m$ indicates the weight of the soaked rock $(\mathrm{kg})$.

As a result, the release rate of base cations is expressed by equation [2]:

$$
V_{T}=\sum S_{i\left(i=K^{+}, \mathrm{Na}^{+}, \mathrm{Ca}^{2+}, \mathrm{Mg}^{2+}\right)} / t[2]
$$

where $V_{T}$ is the total release rate of the base cations $\mathrm{K}^{+}, \mathrm{Na}^{+}, \mathrm{Ca}^{2+}$ and $\mathrm{Mg}^{2+}$ in each treatment cycle $\left(\mathrm{mmol} \mathrm{kg}{ }^{-}\right.$ $\left.{ }^{1} \mathrm{~h}^{-1}\right)$ and $t$ is the duration time of each soaking (h).

\subsection{Data analysis and statistics}

Multiple comparisons are used to analyze the effects of different treatments and parent rock types on the amounts of cation release. Analyses of the least significant difference (LSD) tests were performed using the SPSS v.12.0 software to determine whether the amounts of cations released were significantly different for the various acid treatments. After regression analysis, the models of the relationship between the variables were set up via the regressive determination parameters compared by the ORIGIN v.8.0 software. The statistically significant level was set at $p<0.05$, and the statistical parameters for all of the data were then analyzed using SPSS v.12.0.

\section{Result}

\subsection{Release of cations in the soaking solution}

The variation trend of cations in the soaking solution of parent rocks under different acid treatments is similar, that was, the stronger the acid treatment accompanied with the higher the release amount of each cation (Fig. 1). During the whole soaking process, the release amount of each cation under $\mathrm{pH} 2.5$ treatment was significantly greater than that under other acid treatments. The $\mathrm{K}^{+}$release process of the two groups of parent rocks under $\mathrm{pH} 2.5$ immersion showed a single peak curve, and obvious peaks appeared in the middle stage of immersion, with the release amounts of $0.037 \mathrm{mmol} / \mathrm{kg}$ and $0.038 \mathrm{mmol} / \mathrm{kg}$ from $J_{2} \mathrm{~s}$ and $J_{3} p$ respectively, and then showed a fluctuating downward trend to tend to be stable. The released $\mathrm{K}^{+}$of $\mathrm{J}_{2} \mathrm{~s}$ under pH 3.5, $\mathrm{pH} 4.5, \mathrm{pH}$ 5.6 and CK treatments were relatively gentle, with little fluctuation and unobvious peak value. However, the $\mathrm{K}^{+}$ release from $\mathrm{J}_{3}$ p showed two obvious peaks during soaking between $\mathrm{pH} 3.5 \sim \mathrm{pH} 7.0$, and the release showed a slow downward trend after the second peak change. The release laws of $\mathrm{Na}^{+}$between two parent rocks were basically similar, that the overall trend was fluctuating and declining with the soaking process. $\mathrm{Na}^{+}$release of $\mathrm{J}_{3} \mathrm{p}$ under different $\mathrm{pH}$ acid solution treatment had obvious fluctuation peak in the middle stage of immersion, while it decreased continuously from the beginning of soaking in the $\mathrm{J}_{2} \mathrm{~s}$. $\mathrm{Na}^{+}$increased slightly under $\mathrm{pH} 2.5$ treatment in the later stage of soaking, while under other $\mathrm{pH}$ treatment $\mathrm{Na}^{+}$release decreased slowly and the curve changed gently. The $\mathrm{Ca}^{2+}$ release curves of $\mathrm{J}_{2} \mathrm{~s}$ and $\mathrm{J}_{3} \mathrm{p}$ in strong acid $(\mathrm{pH}=2.5)$ solution were similar, which had a single peak curve trend, and arrived the peak value of $0.912 \mathrm{mmol} / \mathrm{kg}$ and $1.417 \mathrm{mmol} / \mathrm{kg}$ 
respectively at the 10 th immersion. The $\mathrm{Ca}^{2+}$ release laws of $\mathrm{J}_{2} \mathrm{~s}$ under $\mathrm{pH} 3.5$ to $\mathrm{pH} 7.0$ were similar to that under the treatment of strong acid solution with $\mathrm{pH} 2.5$, and a relative high peak appears in the middle stage of soaking, and then had a fluctuating downward trend. However, the $\mathrm{Ca}^{2+}$ release curves of $\mathrm{J}_{3} \mathrm{p}$ under the treatment of acid solution with $\mathrm{pH}$ value of $3.5 \sim 7.0$ were consistent, and the $\mathrm{Ca}^{2+}$ release amount were relatively high at the beginning of soaking. With the soaking cycle, the $\mathrm{Ca}^{2+}$ release curve fluctuated and the decline range was large at the beginning stage, and it decreased slowly or tends to be gentle at the later stage. The release law of $\mathrm{Mg}^{2+}$ under different acid treatments were similar to that of $\mathrm{Na}^{+}$. With the progress of soaking process, the overall trend of $\mathrm{Mg}^{2+}$ were fluctuating and declining, and the release of $\mathrm{Mg}^{2+}$ rapidly decreases to a relatively low value during the middle stage of soaking.

\subsection{The effect of pH on the amount of cations released}

The amounts of elements released by weathering (the unit charge of elements released from $1 \mathrm{~kg}$ of soil during the weathering process) were utilized as a criterion to assess the rate of weathering (Qiu and Yang, 1998). In this study, the amounts of $\mathrm{K}^{+}, \mathrm{Na}^{+}, \mathrm{Ca}^{2+}$ and $\mathrm{Mg}^{2+}$ released from $\mathrm{J}_{3} \mathrm{p}$ and $\mathrm{J}_{2}$ s under the effects acid solutions were obvious after 24 treatment cycles. As Table 3 showed, the acid solutions caused more cations to be released than the deionized water for the two rock types. The whole amount of cations released from all of the studied types of rocks enhanced as $\mathrm{pH}$ diminished, particularly when $\mathrm{pH}$ was less than 3.5 , and a significant difference $(p<0.05)$ was observed after the acid treatments. Compared with the control treatment of $\mathrm{pH} 7.0$ $(\mathrm{CK})$, the amount of cations released from sample $\mathrm{J}_{3} \mathrm{p}$ after treatment with solutions of $\mathrm{pH} 2.5,3.5,4.5$ and 5.6 increased by multiples of $6.50,1.55,1.25$ and 1.14 times, respectively. Comparable values were 8.23, 1.74, 1.41

and 1.22 times for $\mathrm{J}_{2} \mathrm{~s}$. Compared to the $\mathrm{CK}$, the $\mathrm{Ca}^{2+}$ released from the $\mathrm{pH} 2.5$ solution apparently increased by 19.59 and 9.59 mmol kg ${ }^{-1}$ for $\mathrm{J}_{3} \mathrm{p}$ and $\mathrm{J}_{2} \mathrm{~s}$, respectively, and $\mathrm{Mg}^{2+}$ increased by 1.20 and $5.82 \mathrm{mmol} \mathrm{kg}^{-1}$. Compared with monovalent cation species, the $\mathrm{H}^{+}$concentrations, to a large degree, restricted the release of $\mathrm{Ca}^{2+}$ and $\mathrm{Mg}^{2+}$ when the $\mathrm{pH}$ of the applied solution was lower than 3.5. The release of base cations showed a certain relationship with the composition of the minerals. $\mathrm{Ca}^{2+}$ was the predominant cation released under the various acid solutions, with the average $\mathrm{Ca}^{2+}$ amount accounting for $49.80 \%$ for the two rock types, while $\mathrm{Na}^{+}$ represented33.14\%, $\mathrm{Mg}^{2+} 10.96 \%$ and $\mathrm{K}^{+} 6.09 \%$.

\subsection{Relationship between the amount of cations released and $\mathrm{pH}$}

The tendency for specific cations to be released under different acidic solutions was similar for the two rock groups. Regression analysis showed that the amount of released individual cations appeared to exponentially decrease as $\mathrm{pH}$ increased in all two of the rock types tested. The exponential correlations between $\mathrm{pH}$ and cation release were significant $(p<0.001)$, especially for the amount of $\mathrm{Ca}^{2+}$ and $\mathrm{Mg}^{2+}$ released, with correlation coefficients $\left(R^{2}\right)$ above 0.999 (Fig. 2). This also illustrated that the sensitivity of cation release to $\mathrm{pH}$ variation for the various cation types was high for all two rock types and that $\mathrm{Ca}^{2+}$ and $\mathrm{Mg}^{2+}$ were more apparent than $\mathrm{K}^{+}$ 
and $\mathrm{Na}^{+}$. On the whole, these data fit the proposed model and were able to correctly and quantitatively predict the cation amounts released from purple rock under varying acidic environmental conditions in the laboratory.

\subsection{Determination of the quantitative relationship between cation release rates and $\mathrm{H}^{+}$concentrations}

Intuitively, it can be expected that acid would exert a strong influence on chemical weathering; however, this effect may vary with environmental changes such as air temperature. Many researchers (Yang and Brantley, 1997; Gislason and Oelkers, 2003; Gudbrandsson et al., 2011) have studied the effects of pH and temperature on mineral dissolution kinetics. Previous studies indicated that the rate of water exchange around an octahedral cation can be correlated to the mineral dissolution rates in orthosilicates (Casey and Westrich, 1992). In general, the net total output of base cations $\left(\mathrm{K}^{+}, \mathrm{Na}^{+}, \mathrm{Ca}^{2+}\right.$ and $\left.\mathrm{Mg}^{2+}\right)$ is used to represent 'chemical weathering' (Paces, 1986); therefore, to provide credible estimates, the chemical weathering rate in acidic environments should be considered and incorporated into future models. To effectively describe the reaction of rock to acidic experimental environments in the laboratory, a total of 120 sets (24 cycles of five treatments) of data were analyzed, including chemical weathering rates, $\mathrm{H}^{+}$concentration of the soaking solution and natural temperature (Fig. 3). Using nonlinear, multivariate regression, Eq. (3) was formulated :

$$
V_{T}=e^{a c}\left(H^{+}\right) \cdot\left(\frac{A}{R T}\right)^{\beta}[3]
$$

where $V_{T}$ is the same as in equation [2], $C\left(H^{+}\right)$is the concentration of $\mathrm{H}^{+}\left(\mathrm{mmol} \mathrm{L}^{-1}\right), T$ is temperature (K) (Fig. 3), $R$ is the gas constant ( $\mathrm{kJ} \mathrm{mol}^{-1} \mathrm{~K}^{-1}$ ) and $\mathrm{a}, \beta$ and $A$ are constants to be determined by regression analysis and are dependent on rock material properties.

In this study, the chemical weathering rate of base cations was calculated and combined with other variables in equation [3] using SPSS v.12.0, and the results showed that the data fit the model to a significant degree $(p<$ 0.001). The correlation coefficients of the cation release rates related to the concentrations of $\mathrm{H}^{+}$were 0.897 and 0.767 for $\mathrm{J}_{3} p$ and $\mathrm{J}_{2} \mathrm{~s}$, respectively, and they were apparently greater than those related to temperature, which were 0.045 and 0.116 for $\mathrm{J}_{3} p$ and $\mathrm{J}_{2} \mathrm{~s}$, respectively. The multiple correlation coefficients $\left(R^{2}\right)$ were above 0.883 and were higher than the partial correlation coefficients (Table 4). Thus, our results showed that the model of chemical weathering rates was not satisfactory when the rate was determined only based on solution acidity $(\mathrm{pH})$ without consideration of the temperature effects.

\section{Discussion}

A remarkable number of laboratory investigations have illustrated the essential role of $\mathrm{pH}$ in the processes of chemical weathering (Schnoor, 1990; Guicharnaud and Paton, 2006). In this study, our results indicates that the concentration of $\mathrm{H}^{+}$in the reaction environment is an important impact factor for weathering kinetics, consistent with those of previous studies (Huang et al., 2013; Wu et al., 1998; Zhang et al., 2007; Probst et al., 1992). The rate of the release of cations from the purple rocks obviously enhanced as the solution $\mathrm{pH}$ diminished, especially when the value of $\mathrm{pH}$ was less than 3.5 (Table 3). Similarly, the effect of acidification on 
chemical weathering is low (Sverdrup and Warfvinge, 1995), therefore, long-term evaluation is necessary to reveal the effects of acid deposition on chemical weathering (Probst et al., 1992). However, a pH less than 3.5 is infrequent in natural environments, the impacts of acidity on chemical weathering involve the relatively long procedures, and in simulation assessments, a lesser $\mathrm{pH}$ is commonly utilized to stimulate the long-lasting impacts of acidic media in nature to diminish the involvement of humidity, temperature, and other external parameters (Liu et al., 2010). In the current research, the performed analysis of cation release divulged substantial impacts of $\mathrm{pH}$ on chemical weathering among the two purple rocks, particularly when the amount of $\mathrm{Mg}^{2+}$ and $\mathrm{Ca}^{2+}$ released during the $\mathrm{pH} 2.5$ processing was considered. The effects were significantly greater than those caused by the other treatments, which was attributed to the fact that compared to univalent cations, the divalent cations released were more affected by the $\mathrm{pH}$ of the environment (Liu et al., 1990; Hartikainen, 1996). Calcium in the rock mainly exists in inorganic form, and inorganic calcium can be further divided into mineral and exchange state calcium (Yuan, 1983). Of these, mineral calcium mainly exists in the crystal lattice of the rock in its solid phase and can seldom be released through hydrolysis. In contrast, the calcium-bearing minerals in purple rock are mainly silicate minerals and carbonate minerals. The acidities of silicic acid and carbonic acid are weaker than those of the simulated solutions due to the action of mixed acids of $\mathrm{SO}_{4}{ }^{2-}$ and $\mathrm{NO}_{3}{ }^{-}$. In this way, the calcium within silicate and carbonate minerals can be easily dissolved by acid. In contrast, the released quantity of potassium is evidently lower than that of calcium, which is mainly because most of the calcium-bearing primary minerals in the rock are easily weathered. In particular, the weathering rate of calcium-bearing plagioclase is much higher than that of potassium feldspar or sodic feldspar (Yuan, 1983). Meanwhile, the lattice energy of calcium-bearing minerals is much smaller than those of sodium- or potassiumcontaining minerals of the same type (Yuan, 1983). Additionally, the major clay minerals of the purple block (including illite, montmorillonite, and chlorite) are all phyllosilicate-based minerals with a ratio of 1:2 in illite and montmorillonite and in chlorite a ratio of 2:1:1 (Verburg and Baveye, 1994). The reactions of these minerals in acidic solutions may represented as follows:

Montmorillonite (Amram and Ganor, 2002):

$\left(\mathrm{K}_{0.02} \mathrm{Na}_{0.05} \mathrm{Ca}_{0.41} \mathrm{Mg}_{0.18}\right)\left(\mathrm{Mg}_{1.11} \mathrm{Fe}_{0.17} \mathrm{Al}_{2.77}\right)$

$\left(\mathrm{Al}_{0.3} \mathrm{Si}_{7.7}\right) \mathrm{O}_{20}(\mathrm{OH})_{4}+13.2 \mathrm{H}^{+}+6.8 \mathrm{H}_{2} \mathrm{O} 0.02 \mathrm{~K}^{+}+0.05 \mathrm{Na}^{+}+0.41 \mathrm{Ca}^{2+}+1.29 \mathrm{Mg}^{2+}+0.17 \mathrm{Fe}^{3+}+3.07 \mathrm{Al}^{3+}+7.7 \mathrm{H}_{4} \mathrm{SiO}_{4}$

Illite (Vieillard, 2000):

$\left(\mathrm{Si}_{3.55} \mathrm{Al}_{0.45}\right)\left(\mathrm{Al}_{1.27} \mathrm{Fe}^{(\mathrm{IIII})}{ }_{0.36} \mathrm{Mg}_{0.44}\right) \mathrm{O}_{10}(\mathrm{OH})_{2}\left(\mathrm{Ca}_{0.01} \mathrm{Na}_{0.13} \mathrm{~K}_{0.53}\right)+7.80 \mathrm{H}^{+} 3.55 \mathrm{SiO}_{2}+1.72 \mathrm{Al}^{3+}+0.36 \mathrm{Fe}^{3+}+0.44$ $\mathrm{Mg}^{2+}+0.01 \mathrm{Ca}^{2+}+0.13 \mathrm{Na}^{+}+0.53 \mathrm{~K}^{+}+4.90 \mathrm{H}_{2} \mathrm{O}$

Chlorite (Tang et al., 2007):

$(\mathrm{Mg}, \mathrm{Fe}, \mathrm{Al})_{6}\left[\mathrm{AlSi}_{3} \mathrm{O}_{10}\right](\mathrm{OH})_{8}+16 \mathrm{H}^{+}[6(\mathrm{Mg}, \mathrm{Fe}, \mathrm{Al})]^{13+}+\mathrm{Al}^{3+}+3 \mathrm{H}_{4} \mathrm{SiO}_{4}+6 \mathrm{H}_{2} \mathrm{O}$

These reactions promoted the replacement of intercrystalline $\mathrm{Ca}^{2+}, \mathrm{Mg}^{2+}, \mathrm{Fe}^{3+}$ and $\mathrm{Na}^{+}$by $\mathrm{H}^{+}$in the solution. However, the crystal structure of illite, which accounts for the vast majority of the clay mineral composition of the rock, constitutes two tetrahedral sheets with face-to-face top oxygen molecules. Moreover, the layers are tightly stacked in a staggered arrangement, and a coordinate, co-edge, octahedral combination is produced by 
the superposition, forming an octahedral sheet (0). Thus, a basic structural layer is formed, the interlayer space of which is filled with $\mathrm{K}^{+}$with an equilibrium electrovalence. The $\mathrm{K}^{+}$exposed between the layers is directly absorbed onto the silica tetrahedra and is not easily replaced by $\mathrm{H}^{+}$in the solution.

On the basis of transition state theory, chemical weathering processes may be influenced by the proton or aqueous activities of elements (Zhu et al., 2013). The distribution of cations $\left(\mathrm{K}^{+}, \mathrm{Na}^{+}, \mathrm{Ca}^{2+}\right.$ and $\left.\mathrm{Mg}^{2+}\right)$ on the ternary diagrams presented in Fig. 4 can be used to indicate the relative contributions of major ions under various acidic environments (Huh, 2003). Silicate- and carbonate-rich minerals are major components of the purple rock lithologies; therefore, considering that they can be weathered easily (especially carbonates), they are expected to contribute significantly to the major cation budget of the chemical weathering process (Zhu et al., 2013). Therefore, $\mathrm{Ca}^{2+}$ was the dominant species in $\mathrm{J}_{3} \mathrm{p}$ under various acid treatments, while $\mathrm{K}^{+}$and $\mathrm{Na}^{+}$were remarkably high in $\mathrm{J}_{2} \mathrm{~s}$ except for the $\mathrm{pH} 2.5$ treatments. Notably, the relative contributions of major cations to chemical weathering varied with $\mathrm{pH}$ and time. The proportion of $\mathrm{Ca}^{2+}$ released by $\mathrm{pH} \geq 3.5$ treatments was substantially decreased when compared with the $\mathrm{Ca}^{2+}$ released by the treatment at $\mathrm{pH} 2.5$. The proportions of $\mathrm{Na}^{+}$and $\mathrm{K}^{+}$behaved in the opposite manner, and the contribution rate of $\mathrm{Mg}^{2+}$ changed only slightly with changing $\mathrm{pH}$. On average, the release of $\mathrm{Mg}^{2+}$ only accounted for a small fraction of the major cations, and its contribution in $\mathrm{J}_{3} \mathrm{p}$ approached 0 with an increase in time; it should also be noted that the contributions of $\mathrm{Na}^{+}$ and $\mathrm{K}^{+}$increased.

The rate of chemical weathering is usually quantified by measuring solute concentrations and flux (Drever and Zobrist, 1992; Stonestrom et al., 1998). Past research has focused on the effects of changing temperature and reactive fluid composition on the chemical rates of individual minerals in the laboratory (Oelkers and Schott, 2001; Schott et al., 2009). However, natural rocks consist of many different minerals with distinct reactive and surface areas; thus, different rocks have distinct responses to $\mathrm{pH}$ and temperature. Concerning the constituents of its materials, purple rocks include a considerable percentage of clay minerals, namely, illite, montmorillonite, chlorite, and so forth. According to studies of influence factors on clay mineral weathering, the clay mineral dissolution rates increase with temperature strongly depends on pH (Huertas et al.,2001; Köhler et al., 2003), and previous investigations have exhibited that more quickly dissolution could be achieved by a departure from neutral pH circumstances. Furthermore, at greater temperatures, the rate of solution is greater (Oelkers et al., 2008; Bray et al., 2015). A thorough study on phyllosilicate weathering indicates that the rate of weathering is lesser at low temperatures and moderately acidic to neutral $\mathrm{pH}$, and it is greater at higher temperatures and lower $\mathrm{pH}$, which are divided through a transition zone (Lamarca-Irisarri, et al., 2019). Regression analysis of our results revealed that the relationships between cation release rate, $\mathrm{H}^{+}$concentration and natural temperature were significant for the tw purple rock samples $(\mathrm{p}<0.001)$. According to partial correlation coefficients (Table 4), both the $\mathrm{H}^{+}$concentration and temperature significantly influenced the cation release rates $(\mathrm{p}<$ 0.001). Temperature affected not only the absorption of protons on the surface (Cama et al., 2002) but also the physical erosion of purple rock (Zhang et al., 2015). Previous researchers have indicated a positive relationship between chemical and physical weathering rates (Riebe et al., 2003; Singh et al., 2005). Therefore, any attempts to model cation release rates based on the independent effect of $\mathrm{pH}$ alone and without consideration of temperature effects will be unsatisfactory; our developed model (equation [3]) would be more accurate for the prediction of cation release rates under environments with variable acidity. 


\section{Conclusion}

Our results show that the total amount of base cations $\left(\mathrm{K}^{+}, \mathrm{Na}^{+}, \mathrm{Ca}^{2+}\right.$, and $\left.\mathrm{Mg}^{2+}\right)$ released from purple rock during the chemical weathering process significantly $(P<0.001)$ increases with an increase in $\mathrm{H}^{+}$concentration. The release of $\mathrm{Ca}^{2+}$ is the main contribution to cation release from the $\mathrm{J}_{3} \mathrm{p}$ under various acid treatments, while $\mathrm{K}^{+}$and $\mathrm{Na}^{+}$are the main cations released from the $\mathrm{J}_{2} \mathrm{~s}$, with the exception of the pH 2.5 treatment. The models for cation release rates fit the observed data well when the two variables are introduced (i.e., $\mathrm{H}^{+}$concentration and air temperature), and there is a significant $(P<0.01)$ exponential relationship between the amount of cations released and the $\mathrm{pH}$. Therefore, these models can be considered to be a baseline that will allow the base cation release rates of purple rock to be quantitatively predicted under varying environmental acidification conditions. In conclusion, our results suggest that acidity is a critical driving force in the chemical weathering of purple rock.

\section{Declarations}

\section{Acknowledgements}

This work was supported by the National Natural Science Foundation Committee of China (No.42007002), Yunnan Basic Research Project-general projects (No. 202101AT070220).

\section{Data Availability}

All the data generated and provided in the study is included under the main article and supplementary material file.

\section{References}

1. Amram, K., Ganor, J., 2002. The combined effect of $\mathrm{pH}$ and temperature on smectite dissolution rate under acidic conditions. Geochim Cosmochim Acta. 66, 3913-3926.

2. Birkeland, P.W., 1999. Soil and geomorphology: New York, Oxford University Press, 430p.

3. Bray, A.W., Oelkers, E.H., Bonneville, S., Wolff-Boenisch, D., Potts N, J., Fones, G., Benning, L.G., 2015. The effect of $\mathrm{pH}$, grain size, and organic ligands on biotite weathering rates. Geochim Cosmochim Acta. 164, $127-145$.

4. Cama, J., Metz, V., Ganor, J., 2002. The effect of $\mathrm{pH}$ and temperature on kaolinite dissolution rate under acidic conditions. Geochim. Cosmochim. Acta. 66, 3913-3926.

5. Casey, W.H., Westrich, H.R., 1992. Control of dissolution rates of orthosilicate minerals by divalent metaloxygen bonds. Nature. 355, 157-159.

6. Chen, P.Y., Lin, M.L., Zheng, Z., 1997.On the origin of the name kaolin and the kaolin deposits of the Kauling and Dazhou areas, Kiangsi, China. Appl. Clay Sci. 12, 1-25.

7. Drever, J., Zobrist, J., 1992. Chemical weathering of silicate rocks as a function of elevation in the southern Swiss Alps. Geochim Cosmochim Acta. 56, 3209-3216. 
8. Duan, L., Hao, J.M., Xie, S.D., Zhou, Z.P., Ye, X.M., 2002. Determining weathering rates of soils in China. Geoderma. 110, 205-225.

9. Eppes, M.C., McFadden, L.D., Matti, J., Powell, R., 2002. Influence of soil development on the geomorphic evolution of landscapes: An example from the transverse ranges of California. Geology.30(3):195-198.

10. Gislason, S.R., Oelkers, E.H., 2003. Mechanism, rates and consequences of basaltic glass dissolution: II. An experimental study of the dissolution rates of basaltic glass as a function of $\mathrm{pH}$ and temperature. Geochim Cosmochim Acta. 67, 3817-3832.

11. Goldsmith, S.T., Carey, A.E., Johnson, B.M., Welch, S.A., Lyons, W.B., McDowell, W.H., Pigott, J.S., 2010. Stream geochemistry, chemical weathering and $\mathrm{CO}_{2}$ consumption potential of andesitic terrains, Dominica, Lesser Antilles. Geochim Cosmochim Acta. 74, 85-103.

12. Green, E.G., Dietrich, W.E., Banfiel, J.F., 2006. Quantification of chemical weathering rates across an actively eroding hillslope. Earth Planet Sci Lett. 242,155-169.

13. Gudbrandsson, S., Wolff-Boenisch, D., Gislason, S.R., Oelkers, E.H., 2011. An experimental study of crystalline basalt dissolution from $2 \leqq \mathrm{pH} \leqq 11$ and temperatures from 5 to $75^{\circ} \mathrm{C}$. Geochim Cosmochim Acta. 75, 5496-5509.

14. Guicharnaud, R., Paton, G.I., 2006. An evaluation of acid deposition on cation leaching and weathering rates of an Andosol and a Cambisol. J Geochem Explor. 88, 279-283.

15. Gupta,V., Ahmed, I., 2007.The effect of $\mathrm{pH}$ of water and mineralogical properties on the slake durability (degradability) of different rocks from the Lesser Himalaya, India. Engineering Geology. 95, 79-87.

16. Hartikainen, H., 1996. Soil response to acid percolation: acid-base buffering and cation leaching. J Environ Qual. 25, 638-645.

17. He, Y.R., 2003. Purple Soils in China. Chinese Science Press, Beijing.

18. Hornung, M., Le-Grice, S., Brown, N., Norris, D., 1990. The role of geology and soils in controlling surface water acidity in Wales. In: Edwards R W, Gee A S, Stoner J H. (Eds.). Acid Waters in Wales, Kluwer Academic Publishing, Dordrecht.55-66.

19. Huang, L.M., Zhang, G.M., Yang, J.L., 2013. Weathering and soil formation rates based on geochemical mass balances in a small forested watershed under acid precipitation in subtropical China. Catena. 105, 11-20.

20. Huang, L.M., Yang, J.L., Rossiter, D.G., Thompson, A., Zuo, S.M., Zhang, G.L., 2015. Proton production from nitrogen transformation drives stream export of base cations in acid sensitive forested ecosystems. Ecological Indicators. 48: 348-357

21. Huh, Y., 2003. Chemical weathering and climate-a global experiment: a review. Geosci J. 7: 277-288.

22. Huertas, F.J., Caballero, E., Jiménez, de.Cisneros.C., Huertas, F., Linares, J., 2001. Kinetics of montmorillonite dissolution in granitic solutions. Appl Geochem. 16, 397-407.

23. Kirschbaum, A., Martínez, E., Pettinari, G., Herrero., 2005. Weathering profiles in granites, Sierra Norte (Cordoba, Argentina). J S Am Earth Sci. 19, 479-493.

24. Köhler, S.J., Dufaud, F., Oelkers, E.H., 2003. An experimental study of Illite dissolution kinetics as a function of pH from 1.4 to 12.4 and temperature from 5 to $50^{\circ} \mathrm{C}$. Geochim Cosmochim Acta. 67, 3583 - 594. 
25. Lamarca-Irisarri, D., Driessche, A.E.S.V., Jordan, G., Cappelli, C., Huertas, F.J., 2019. The role of pH, temperature, and $\mathrm{NH}_{4}{ }^{+}$during mica weathering. Acs Earth Space Chemistry. 3, 2613-2622

26. Langan, S.J., Reynolds, B., Bain, D.C., 1996. The calculation of base cations release from mineral weathering in soils from Palaeozoic greywackes and shales in upland UK. Geoderma. 69, 275-285.

27. Langan, S.J., Sverdrup, H.U., Coull, M., 1995. The calculation of base cation release from the chemical weathering of Scottish soils using the profile model. Water Air Soil Poll. 85, 2497-2502.

28. Ling, D.J., Zhang, J.E., Ouyang, Y., Huang, Q.C., 2007. Role of Simulated Acid Rain on Cations, Phosphorus and Organic Matter Dynamics in Latosol. Arch Environ Con Tox. 52,16-21.

29. Liu, J., Li, J.L., Zhang, Y.D., Qu. J.J., Chen, X., Qin, Y.H., 2010. Study of time scale and strength model of Yichang sandstone under different $\mathrm{pH}$ values of acidic solution immersion. Chinese Journal Of Mechanical Engineering. 29, 2319-2327 (in Chinese).

30. Liu, K.H., Mansell, R.S., Rhue, R.D., 1990. Cation removal during application of acid solution into air dry soil columns. Soil Sci Soc Am J. 54, 1747-1753.

31. Ministry of Geology, Resources, Mineral. 2002. GB/T 14506.1-28-93. Standards Press, Beijing (in Chinese).

32. Nesbitt, H.W., Markovics, G., Price, R.C., 1980. Chemical processes affecting alkalis and alkaline earths during continental weathering. Geochim Cosmochim Acta. 44, 1659-1666.

33. Oelkers, E.H., Schott, J., 2001. An experimental study of enstatite dissolution rates as a function of $\mathrm{pH}$, temperature and aqueous $\mathrm{Mg}$ and Si concentration, and the mechanism of pyroxene/pyroxenoid dissolution. Geochim Cosmochim Acta. 65, 1219-1231.

34. Oelkers, E.H., Schott, J., Gauthier, J.M., Herrero-Roncal, T., 2008. An experimental study of the dissolution mechanism and rates of muscovite. Geochim Cosmochim Acta. 72, 4948-4961.

35. Paces T. 1986. Weathering rates of gneiss and depletion of exchangeable cations in soils under environmental acidification. J Geol Soc. 143,673-677.

36. Probst, A., Viville, D., Fritz, B., Ambroise, B., Dambrine, E., 1992. Hydrochemical budgets of a small forested granitic catchment exposed to acid deposition: the Strenbach catchment case study (Vosges Massif, France). Water Air Soil Poll. 62, 337-347.

37. Qiu, R.L., Yang, P., 1998. Study of sensitivity of soil to acid deposition in south China. Weathering characteristics of soil minerals under simulated acid rain. Acta Scientiarum Naturalium Universitatis Sunyatseni. 37, 89-93(in Chinese).

38. Riebe, C.S., Kirchner, J.W., Finkel, R.C., 2003. Long-term rates of chemical weathering and physical erosion from cosmogenic nuclides and geochemical mass balance. Geochim Cosmochim Acta. 67, 4411-4427.

39. Rodhe, H., Dentener, F., Schulz, M., 2002.The global distribution of acidifying wet deposition. Environ Sci Technol. 3, 4382-4388.

40. Schnoor, J.L., 1990. Kinetics of chemical weathering: a comparison of laboratory and field weathering rates. In: Stumm, W. (Ed.), Aquatic Chemical Kinetics. Wiley-Interscience, New York. 475-504.

41. Schott, J., Pokrovsky, O.S., Oelkers, E.H., 2009. The link between mineral dissolution / precipitation kinetics and solution chemistry. Rev Mineral Geochem. 70, 207-258.

42. Singh. S.K., Sarin, M.M., France-Lanord, C., 2005. Chemical erosion in the eastern Himalayas: major ion composition of the Brahmaputra and $\delta 13 \mathrm{C}$ of dissolved inorganic carbon. Geochim Cosmochim Acta. 69, 
3573-3588.

43. Stonestrom, D.A., White, A.F., Akstin, K.C., 1998. Determining rates of chemical weathering in soils-solute transport versus profile evolution. J Hydrol. 209, 331-345.

44. Sverdrup, H., Warfvinge, P., 1995. Estimating field weathering rates using laboratory kinetics. Chemical weathering rates of silicate minerals. In: White A F, Brantley S L (Eds.), Mineralogical Society of America. 31, 485-539.

45. Sverdrup, H., Warfvinge, P., 1998. Weathering of primary silicate minerals in the natural soil environment in relation to a chemical weathering model. Water Air Soil Poll. 38, 387-408.

46. Tang, H.M., Zhao, F., Li, G., Wang, C.H., Xie, X.Y., 2007. Experimental study on reactions of chlorite with mud and fluoboric acids. Oilfield Chemistry. 24, 307-309 (in Chinese).

47. Verburg, K., Baveye, P., 1994. Hysteresis in the binary exchange of cations on 2:1 clay minerals: a critical review. Clays Clay Miner. 42, 207-220.

48. Vieillard, P., 2000. A new method for the prediction of gibbs free energies of formation of hydrated clay minerals based on the electronegativity scale. Clays Clay Miner. 48, 459-473.

49. Wang, H., Han, G., 2011. Chemical composition of rainwater and anthropogenic influences in Chengdu, Southwest China. Atmos. Res. 99 (2), 190-196.

50. Warke, P., 2000. Micro-environmental conditions and rock weathering in hot, arid regions. Zeitchrift für Geomorphologie. Supplementary Band. 120, 83-95.

51. Wu, Q., Qiu, R.L., Lu, Y.N., 1998. Effects of simulated acid rain on cation releasing in soils of south China. J Environ Sci. 10, 309-315.

52. Yang, X.H., Shu, L., Chen, S.L., 2014. Study on Changing characteristics of acid rain and chemistry composition of rain water in Nanchong in recent decades. Sichuan Environment. 33, 26-31(in Chinese).

53. Yang, C., Brantley, S.L., 1997. Temperature- and $\mathrm{pH}$-dependence of albite dissolution rate at acid pH. Chem Geol. 135, 275-290.

54. Yuan, K.N., 1983. Soil chemistry of plant nutrient elements. Science Press, Beijing(in Chinese).

55. Zhang, D., Chen, A.Q., Wang, X.M., Liu, G.C., 2015. Quantitative determination of the effect of temperature on mudstone decay during wet-dry cycles: A case study of 'purple mudstone' from south-western China. Geomorphology. 246, 1-6.

56. Zhang, D., Chen, A.Q., Liu, G.C., 2012. Laboratory investigation of disintegration characteristics of purple mudstone under different hydrothermal conditions. J MT Sci-Engl. 9, 127-136.

57. Zhang, D., Chen. A.Q., Xiong, D.H., Liu, G.C., 2013. Effect of moisture and temperature conditions on the decay rate of purple mudstone in southwestern China. Geomorphology. 182, 125-132.

58. Zhang, D., Chen, A.Q., Zhao. J.X., Lu, C.H., Liu, G.C., 2017. Quantitative model prediction of the combined effect of moisture content and temperature on purple mudstone decay in south-western China.

Geomorphology. 295, 656-661.

59. Zhang, Y.K., Fan, G., 2003. Quantitative analytic method and experiments of X-ray diffration phase of clay minerals. Uranium Geology. 180-185(in Chinese).

60. Zhang, J.E., Ouyang, Y., Ling, D.J., 2007. Impacts of simulated acid rain on cation leaching from the Latosol in south China. Chemosphere. 67, 2131-2137. 
61. Zhang, X.M., Chai, F.H., Wang, S.L., Sun, X.Z., Han, M., 2010. Research progress of acid precipitation in China. Research of Environmental Sciences. 23,527-532 (in Chinese).

62. Zhao, M., Li, L., Liu, Z., Chen, B., Huang, J.Q., Cai, J.W., Deng, S.H., 2013. Chemical composition and sources of rainwater collected at a semi-rural site in Ya'an, southwestern China. Atmos. Clim. Sci. 3 (4), 486-496.

63. Zhao, X.L., Yan, J., Chen, Z.Y., Huang, X.L., Guo, X., Sun, Y., 2015. Variation characteristics analysis of acid rain in Sichuan from 2006 to 2013. Meteorological and Environmental Sciences. 38, 54-59(in Chinese).

64. Zhou, C.Y., Tan, X.S., Deng, Y.M., Zhang, L.M., Wang, J.H., 2005. Research on softening micro-mechanism of special soft rocks. Chinese Journal of Rock Mechanics and Engineering. 24:394-400(in Chinese).

65. Zhou, X.D., Xu, Z.F., Liu, W.J., Wu, Y., Zhao, T., Jiang, H., 2017. Progress in the studies of precipitation chemistry in acid rain areas of southwest China. Environmental Science. 38, 4438-4446(in Chinese).

66. Zhu, B., Gao, M.R., Liu, G.C., Liu, R.G., Tsunekawa, A., 1999. Weathering erosion and environmental effects of purple shale. Journal of Soil Erosion and Water Conservation. 5, 33-37(in Chinese).

67. Zhu, B.Q., Yu, J.J., Qin, X.G., Rioual, P., Zhang, Y.C., Liu, Z.T., Mu, Y., Li, H.W., Ren, X.Z., Xiong, H.G., 2013. Identification of rock weathering and environmental control in arid catchments (northern Xinjiang) of Central Asia. J Asian Earth Sci. 66, 277-294.

\section{Tables}

Table 1 Mineral contents (\%) of the two purple mudstones

\begin{tabular}{llllllllll}
$\begin{array}{l}\text { Rock } \\
\text { types }\end{array}$ & $\begin{array}{l}\text { Montmoril- } \\
\text { lonite }\end{array}$ & Illite & Kaolinite & Chlorite & Quartz & $\begin{array}{l}\text { Potassium } \\
\text { feldspar }\end{array}$ & $\begin{array}{l}\text { Plagio- } \\
\text { clase }\end{array}$ & Calcite & Dolomite \\
\hline $\mathrm{J}_{2} \mathrm{~S}$ & 13 & 21 & 6 & 7 & 41 & 2 & 10 & 0 & 0 \\
\hline $\mathrm{J}_{3} \mathrm{P}$ & 5 & 23 & 0 & 11 & 38 & 1 & 8 & 12 & 2
\end{tabular}

Table 2 Major chemical element contents (\%) of the two purple mudstones

\begin{tabular}{|llllllllll|}
\hline Rock types & $\mathrm{SiO}_{2}$ & $\mathrm{Al}_{2} \mathrm{O}_{3}$ & $\mathrm{Fe}_{2} \mathrm{O}_{3}$ & $\mathrm{TiO}_{2}$ & $\mathrm{~K}_{2} \mathrm{O}$ & $\mathrm{Na}_{2} \mathrm{O}$ & $\mathrm{CaO}$ & $\mathrm{MgO}$ & $\mathrm{CaCO}_{3}$ \\
\hline $\mathrm{J}_{2} \mathrm{~S}$ & 61.51 & 16.21 & 6.55 & 0.78 & 2.59 & 1.29 & 0.86 & 2.04 & 2.15 \\
\hline $\mathrm{J}_{3} \mathrm{P}$ & 58.26 & 13.03 & 4.68 & 0.64 & 2.43 & 0.87 & 5.01 & 1.25 & 14.65 \\
\hline
\end{tabular}

\section{Table 3 Amounts of cations released from purple rock under various $\mathrm{pH}$ weathering conditions}




\begin{tabular}{|llllll|}
\hline Rock types & $\mathrm{pH}$ & \multicolumn{4}{l}{ Amount of cations released $\left(\mathrm{mmol} \mathrm{kg}{ }^{-1}\right)$} \\
\cline { 3 - 6 } & & $\mathrm{K}^{+}$ & $\mathrm{Na}^{+}$ & $\mathrm{Ca}^{2+}$ & $\mathrm{Mg}^{2+}$ \\
\hline \multirow{3}{*}{$\mathrm{J}_{2} \mathrm{~S}$} & 2.5 & $0.61 \pm 0.03 \mathrm{a}$ & $3.19 \pm 0.21 \mathrm{a}$ & $10.43 \pm 0.20 \mathrm{a}$ & $6.12 \pm 0.05 \mathrm{a}$ \\
& 3.5 & $0.29 \pm 0.02 \mathrm{~b}$ & $2.09 \pm 0.13 \mathrm{~b}$ & $1.30 \pm 0.03 \mathrm{~b}$ & $0.62 \pm 0.03 \mathrm{~b}$ \\
& 4.5 & $0.26 \pm 0.01 \mathrm{c}$ & $1.78 \pm 0.14 \mathrm{c}$ & $1.05 \pm 0.05 \mathrm{c}$ & $0.39 \pm 0.02 \mathrm{c}$ \\
& 5.6 & $0.20 \pm 0.01 \mathrm{~d}$ & $1.49 \pm 0.14 \mathrm{~d}$ & $0.97 \pm 0.03 \mathrm{c}$ & $0.36 \pm 0.01 \mathrm{c}$ \\
& $\mathrm{CK}$ & $0.18 \pm 0.01 \mathrm{de}$ & $1.15 \pm 0.07 \mathrm{e}$ & $0.84 \pm 0.02 \mathrm{~d}$ & $0.30 \pm 0.02 \mathrm{~d}$ \\
$\mathrm{~J}_{3} \mathrm{p}$ & 2.5 & $0.76 \pm 0.02 \mathrm{a}$ & $2.37 \pm 0.28 \mathrm{a}$ & $22.08 \pm 0.25 \mathrm{a}$ & $1.46 \pm 0.05 \mathrm{a}$ \\
& 3.5 & $0.40 \pm 0.01 \mathrm{~b}$ & $1.77 \pm 0.17 \mathrm{~b}$ & $3.82 \pm 0.05 \mathrm{~b}$ & $0.35 \pm 0.01 \mathrm{~b}$ \\
& 4.5 & $0.33 \pm 0.01 \mathrm{c}$ & $1.49 \pm 0.14 \mathrm{bc}$ & $2.97 \pm 0.02 \mathrm{c}$ & $0.32 \pm 0.01 \mathrm{bc}$ \\
& 5.6 & $0.32 \pm 0.04 \mathrm{c}$ & $1.33 \pm 0.15 \mathrm{~cd}$ & $2.72 \pm 0.03 \mathrm{~d}$ & $0.29 \pm 0.01 \mathrm{~cd}$ \\
\hline & $\mathrm{CK}$ & $0.30 \pm 0.03 \mathrm{c}$ & $1.05 \pm 0.11 \mathrm{e}$ & $2.49 \pm 0.05 \mathrm{e}$ & $0.26 \pm 0.01 \mathrm{e}$ \\
\hline
\end{tabular}

Note: Different letters in a column indicate significant differences between the treatments, where $P<0.05$.

Table 4 Quantitative model of cation release rates for the two groups of rock

\begin{tabular}{|c|c|c|c|c|c|}
\hline \multirow{2}{*}{$\begin{array}{l}\text { Rock } \\
\text { groups } \\
\\
\mathrm{J}_{2} \mathrm{~S}\end{array}$} & \multirow{2}{*}{$\begin{array}{l}\text { Regression equations } \\
v_{T}=e^{0.61 \cdot c_{\left(H^{+}\right)}} \cdot\left(\frac{3853.10}{R T}\right)^{-14.02}\end{array}$} & \multirow{2}{*}{$\begin{array}{l}\text { Correlation coefficients } \\
\left(R^{2}\right) \\
0.883\end{array}$} & \multicolumn{2}{|c|}{$\begin{array}{l}\text { Partial correlation } \\
\text { coefficients } \\
\left(R_{c_{\left(\mathrm{H}^{+}\right)}}^{2}, R_{T}^{2}\right)\end{array}$} & $p$ \\
\hline & & & 0.767 & 0.116 & $<0.001$ \\
\hline$J_{3} p$ & $v_{T}=e^{0.56 \cdot C_{\left(H^{+}\right)}} \cdot\left(\frac{5472.96}{R T}\right)^{-7.34}$ & 0.942 & 0.897 & 0.045 & $<0.001$ \\
\hline
\end{tabular}

\section{Figures}

Figure 1 
Cations released in the soaking solution from $\mathrm{J}_{2} \mathrm{~s}(\mathrm{a})$ and $\mathrm{J}_{3} \mathrm{p}(\mathrm{b})$ after each treatment cycle. Note: The inserts in Fig. 1 show enlargements of the parts of released $\mathrm{Ca}^{2+}$ and $\mathrm{Mg}^{2+}$ with the $\mathrm{pHs}$ of 3.5, 4.5, 5.6 and CK.

\section{Figure 2}

Relationship between the total cations $\left(\mathrm{K}^{+}, \mathrm{Na}^{+}, \mathrm{Ca}^{2+}\right.$ and $\left.\mathrm{Mg}^{2+}\right)$ released and $\mathrm{pH}$

\section{Figure 3}

Average air temperature during each soaking treatment

\section{Figure 4}

Ternary diagrams showing the cation compositions of purple rocks $\mathrm{J}_{3} \mathrm{p}(\mathrm{a})$ and $\mathrm{J}_{2} \mathrm{~s}(\mathrm{~b})$ from the filtered solutions used in the present study

\section{Supplementary Files}

This is a list of supplementary files associated with this preprint. Click to download.

- Datalegends.docx

- supplementalmaterial.zip 